\author{
Mustafa BAKIRCI \\ Dr. Öğr. Üyesi \\ Giresun Üniversitesi, Fen-Edebiyat Fakültesi, Sosyoloji Bölümü, Giresun -TÜRKIYYE \\ Giresun University, Faculty of Art and Sciences, Department of Sociology, Giresun -TURKEY \\ ORCID: 0000-0003-3645-5480 \\ mubakirci@hotmail.com
}

\title{
Modernliğin Sıkıntılarına İrfani-Tasavvufi Anlayış ve Geleneğin Çözüm Oluşturma İmkânı*
}

Öz

Modernlik ve modernliğin sıkıntılarına dair devasa bir literatürün olduğu bilinmektedir. Literatürün en bilindik örneklerine bakıldığında, modernliğin sıkıntıları konusunda, "bireycilik", "araçsal akıl”, "siyasal düzlem”, “tüketim toplumu”, "sinirsel (neural) hastalıklar” gibi konuların ön plana çıktığı görülmektedir.

Makale, modernliğin sıkıntılarına yönelik olarak ortaya koyulan konulara, İslam entelektüel geleneği içerisinde önemli bir yeri olan irfani-tasavvufi anlayış ve geleneğin çözüm oluşturabilme imkânını tartışmaya açmayı amaçlamaktadır.

İfani-tasavvufi anlayış ve geleneğin, modernliğin ortaya çıkardığı sıkıntılar içerisinde yer alan "tüketim toplumu" ve sinirsel (neural) hastalıklar konularına çözüm getirme bakımından güçlü imkânlara sahip olduğu, ancak "bireycilik" ve "araçsal akıl” konularına çözüm olabilme imkânının düşük olduğu değerlendirilmektedir.

Anahtar kelimeler: Modernlik, Modernliğin Sıkıntıları, İrfani-Tasavvufi Anlayış ve Gelenek.

\section{Possibility of Resolving the Problems of Modernity by Sufi Perspective and Tradition}

\begin{abstract}
It is known that there is a vast literature on modernity and its problems. The most well-known literature mainly focuses on issues such as "individualism", "instrumental rationality", "consumption society" and "neural diseases".

This article aims to open a room for dicussion regarding the problems of modernity by approaching them with Sufi perspective and tradition, which constitutes a great part of the Islamic intellectual tradition.

While Sufi perspective and tradition has a slight chance of resolving the matters of "individualism" and "instrumental rationality", it offers a possibility to solve the problems related with "consumption society" and "neural diseases".
\end{abstract}

Keywords: Modernity, Problems of Modernity, Sufi Perspective and Tradition.

\footnotetext{
* Bu makale, 26-28 Eylül 2016 tarihlerinde İstanbul'da gerçekleştirilen, Geçmişten Geleceğe Hoca Ahmet Yesevi Uluslararası Sempozyumu'unda sunulan, "Modern Dünyanın Bunalımlarına Tasavvufî/İrani Yaklaşımların/Geleneğin Çözüm Oluşturma İmkânı-Hoca Ahmed Yesevi Örneği”" (Bakırc1, 2016) tebliğin teorik kısmının genişletilmesiyle oluşmuştur.
} 


\section{Giriş}

Sosyoloji bilimini ortaya çıkaran ve disiplinin en temel ilgi alanlarından biri olan "modernlik"; 17. yüzyıldan 19. yüzyıla kadar Batı Avrupa ve Kuzey Amerika'daki toplumsal, ekonomik ve politik sistemlerde meydana gelen değişimin bir ürünü olarak gelişen, sonrasında diğer Avrupa ülkelerine ve dünyanın diğer coğrafyalarına yayılan bir süreç olarak tanımlanmaktadır. Genel olarak Avrupa'nın tarihsel tecrübesi içinden çıkan ve kendine has bir toplumsal anlayış, yaşam ve örgütlenme biçimi ortaya koyan bu deneyimin, günümüzde neredeyse bütün toplumsal yap1 ve kurumları derinden etkilediği görülmektedir (Eisenstadt, 2007, s. 11; Giddens, 1996; Taylor, 2011). Modernliğin sonradan etkisi altına giren toplumların durum ve deneyimlerine yönelik olarak, "Batı-dışı Modernlik" ve "Çoğulcu Modernlikler" gibi kavramların kullanıldığı bilinmektedir (Eisenstadt vd, 2002; Göle, 2004). Toplumların yaşam pratiklerinde ciddi etkisi olan modernliğin, sosyolojinin öncü ve kurucu isimleri olarak kabul edilen, Claude Henri de Saint-Simon, Auguste Comte, Karl Marx, Emile Durkheim, Herbert Spencer, Max Weber ve Georg Simmel gibi isimlerden günümüze kadar onlarca ismin değerlendirme ve eleştirilerine konu olması, kaçınılmaz olarak devasa bir literatürün oluşmasına neden olmuştur. Bu makalede, modernliğe yönelik eleştirilerin en bilindik örneklerinden hareketle, temel eleştiri alanlarına yönelik genel bir çerçeve çizilmeye çalışılacaktır.

Kavrama yönelik en sert eleştirilerin, yine modernliğin ortaya çıktığı Avrupa başta olmak üzere, Amerika Birleşik Devletleri'nin (ABD) de dâhil olduğu "Batı dünyası" içerisinden üretilerek, modernliğin "sıkıntılarından", "bunalımından" bahsedilmesi (Solmaz, 2011) şüphesiz ki ironik ancak bir sosyal bilimci için oldukça anlaş1lır bir durumdur. Genel olarak ifade etmek gerekirse, bu eserler modernliğin sıkıntılarının kaynaklarına dair çeşitli tespit ve analizler sunmaktadır. Bu makale, İslam entelektüel geleneği içerisinde önemli bir yere sahip olan irfani-tasavvufi anlayış ve geleneğin modern dünyanın bunalım ve sıkıntılarına çözüm oluşturabilme imkânını sorgulamaya açmaktadır.

Burada kullanılan “irfani-tasavvufi anlayış ve gelenek” ifadesi ile İslam'ın ortaya çıkışından günümüze kadar, Müslüman toplumların anlayış ve pratiklerine derinden etki eden ve daha ziyade İslam'ın "romantik" tarafını temsil ettiği varsayılan anlayış ve gelenek işaret edilmektedir. İslam'ın yayılmasında büyük etkisi olduğu bilinen bu anlayış ve gelenekle ilgili esas kastedilen, miladi 7. ve 8. yüzyılları kapsayan "züht dönemi” olmakla birlikte daha sonrası için kullanılan “doktrin dönemi”nin de göz 
önünde bulundurulduğunu belirtmek gerekir (Knysh, 2011; Öngören, 2011; Y1lmaz, 1994).

İrfani-tasavvufi anlayış ve geleneğe yönelik de devasa bir literatürün olduğu ve günümüze kadar hakkında çok çetin tartışmamaların yaşandığı bilinmektedir (Kara, 2003). Ancak makale doğrudan bu tartışmaları konu edinmediği için, değerlendirmeler modern dünyanın sıkıntı ve bunalımlarına çözüm olma imkânı çerçevesinde yapılacaktır. $\mathrm{Bu}$ minvalde, genel olarak üç bölümden oluşan bu makale, sırasıyla modernlik eleştirilerini, irfani-tasavvufi anlayış ve geleneğin içeriğini ve bu anlayış ve gelenek ile modernliğin sıkıntıları arasındaki ilişkiyi ele alacaktır.

\section{Modernlik Eleștirilerinin Temel Dayanakları}

Charles Taylor Modernliğin Sikıntıları (2011, ss. 10, 11) adlı eserinin "üç sıkıntı" başl1klı bölümünde, modern uygarlığın üç büyük sıkıntısının olduğunu ifade etmektedir. Bu sıkıntıların birincisi "bireycilik", ikincisi "araçsal akıl” ve/ya "araçsal aklın öncelik kazanması”, üçüncüsü ise bireyciliğin ve araçsal aklın ortaya çıkardığı “siyasal düzlem”dir.

Taylor'a göre (2011, s. 10) birçok insan “bireycilik”i modern uygarlığın en büyük ve önemli kazanımlarından biri olarak değerlendirir. Bireycilik insanlara, yaşam tarzlarını belirleme, inançlarını bilinçli olarak seçme, atalarının kullan(a)madığı farklı yolları tercih etme hakkını vermiştir. Dolayısıyla birey artık, toplumsal ve ahlaki anlamda özerk bir varlıktır (Ünal, 2011, s. 48). Ancak bu kazanım modern özgürlük öncesi ahlaki ufuklardan kopuş sayesinde elde edilmiştir (Taylor, 2011).

Taylor'un, modernlik-ahlak ilişkisi bağlamında yaptığı değerlendirmede, "ahlaki ufuklardan kopma" veya "ahlaki ufukların solması" şeklinde tanımladığı durum, Alasdair MacIntyre'ın değerlendirmelerinde daha geniş şekilde yer bulur. MacIntyre, Erdem Peşinde (2001) adlı eserinde, doğa bilimlerine ait tüm verileri yok eden bir afet düşlememizi ister. Böyle bir afetten sonra doğa bilimlerini yeniden canlandırmak isteyenlerin elinde kalanlar sadece fragmanlar; kendilerini anlamlı k1lan kuramsal bağlam bilgisinden yoksun parçalar olacaktır. MacIntyre günümüzdeki ahlaki dilin ve durumun da bundan farksız olmadığını; ahlak adına elimizde sadece bir takım fragmanların bulunduğunu ifade eder. Burada dikkat edilmesi gereken nokta, MacIntyre'nın ahlaki dilinin ve ahlaksal olayların varlıklarını bir şekilde sürdürdüklerini görmezlikten gelmediği, ancak ahlaklılığın bütünsel tözünün büyük ölçüde fragmanlara ayrılmış ve tahrip edilmiş olduğunu vurguladığıdır. 
Ahlaki alanın parçalanarak tahribatı, büyük oranda bir "anlam" krizini de beraberinde getirmiş; Weber' in (1993, s. 136) ifadesiyle "büyünün bozulmasına" neden olmuştur. Taylor (2011, ss. 10-13) insanların eskiden kendilerini büyük bir düzenin; kutsal kabullerden dünyadaki diğer varlıklara kadar "Büyük Varoluş Zinciri”nin bir parçası olarak gördüklerini ve bu durumun insanları bir taraftan sınırlarken diğer taraftan da hayatlarına anlam kazandırdığını ifade eder. Ancak bireycilikle birlikte toplumda "büyünün bozulması" ve insanların "Büyük Varoluş Zinciri”nin bir parçası olmaktan çıkmaları, "narsist" ve "hedonist" tutum ve davranışların ortaya çıkmasına neden olmuştur.

Taylor'un (2011, s. 12) modern dünyanın sıkıntıları içinde yer verdiği “araçsal aklın" öncelik kazanması ile kastettiği ise, bireyin belirli bir amaca ulaşmak için araçların en ekonomik olarak nasıl kullanılacağını hesaplamasıdır. Burada başarının ölçüsü, maksimum verimlilik ve en iyi birim fiyatı elde etmektir. Dolayısıyla "verimlilik" ve/ya "maliyet-fayda" değerlendirmesi modern toplumların hayatında en başat unsur haline gelmiştir. Genel bir ifadeyle, "ahlaklı", "erdemli”, "kalıcı" olanın yerine "faydalı" ve "geçici” olan geçmiştir. Horkeimer'ın (1998), “öznel akıl” ve "biçimselleşmiş akıl”" kavramlarıyla eş anlamlı olarak kullandığı "araçsal akıl"; batı düşüncesinde aydınlanma sonrasında oluşan; sadece amaca ulaşmanın ve bunun en kısa ve maliyetsiz şekilde hesaplanmasının elzem olduğu; aklın doğa ve insan üzerinde hâkimiyet kurulmasında rol oynamasının tek ölçüt olarak kabul edildiği "akıl” olarak tanımlanır.

Taylor, (2011, ss. 15, 16) modernliğin üçüncü sıkıntısı olarak, bireyciliğin ve araçsal aklın korkutucu sonuçlarından biri olarak ortaya çıkan bireyin politik olandan uzaklaşmasını işaret eder. Konuyu, Alexis de Tocqueville'in görüşlerinden istifade ederek, insanların "kendi içine kapalı" bireylere dönüş(türül)mesi şeklinde açıklar. Yönetimler, özel yaşamın doyurucu olması için gerekli araçları ürettiği ve yaygın olarak paylaştırdığ 1 sürece, bireyler evlerinde oturup, özel yaşamın keyfini çıkarmayı tercih edeceklerdir. Bu durum, "Demokratik" ve "özgürlükçü" görüntüsünün tersine, halkın siyasi iktidar üzerindeki denetiminin çok az ve sınırlı olduğu bir duruma tekabül etmektedir. Taylor'un dikkat çektiği kavram, Tocqueville'in “yumuşak” despotluk olarak nitelendirdiği, eskisi gibi dehşet ve baskıya dayalı olmayan, yeni ve modernliğe ait bir "despotluk" türüdür.

Taylor'un dile getirdiği bireycilik, aklın araçsallaştırılması ve siyasal düzlemden kopuşla birlikte, modernliğe dair diğer eleştirilerin önemli bir kısmını "gelir 
adaletsizliği”, "üretim ve tüketim çılgınlığı” gibi sosyo-ekonomik alana dair konular oluşturmaktadır. Baudrillard'ın (2008) "Tüketim Toplumu” şeklinde tanımladığı modern toplumlar adeta bir "tüketim çılgınlığı" içerisindedir. Bu "çılgınlığı" oluşturan şey, gerçek ihtiyaçlarla sahte ihtiyaçlar arasındaki ayrımın ortadan kalkması ve tüketimin birey için bir zorunluluğa dönüş(türül)müş olmasıdır. Bu noktada Baudrillard şu soruları sorar: Tüketim doğal ihtiyaçların rasyonel olarak tatmin edilmesi midir? Tüketim ilerleme ve mutluluk anlamına gelir mi? Tüketimin yaygınlaşması sınıf farklılıklarının giderilmesine etki eder mi?

Karl Polanyi, Baudrillard'dan çok önce, ilk baskısı 1944 yılında yapılan Büyük Dönüşüm (2001) adlı eserinde, 19. yüzyıl uygarlığının "kendi kurallarına göre işleyen piyasa"nın oluşturduğu bir dizi problemden dolayı çöktüğünü ifade eder. Polanyi’ye göre 19. yüzyıl uygarlığı dört kuruma dayanmaktaydı. Bunlardan birincisi, bir yüzyıl boyunca büyük güçler arasında uzun ve yıkıcı bir savaşın çıkmasını engelleyen güç dengesi sistemiydi. İkincisi, dünya ekonomisinin benzersiz bir şekilde örgütlenmesini sağlayan uluslararası altın standardıydı. Üçüncüsü, görülmemiş bir maddi refaha yol açan "kendi kurallarına göre işleyen piyasa"ydı. Dördüncüsü ise liberal devletti.

Polanyi’nin "çöküş" olarak değerlendirdiği, modernliğin insanlığı/dünyayı getirdiği bu durumu Bauman, (2015, s. 10) modernliğin mucitlerini "utançtan yerin dibine sokacak bir durum" olarak değerlendirir. Francis Bacon, Descartes ve Hegel'in yaşadığı Aydınlanma Dönemi'nde, dünyanın hiçbir yerinde yaşam standardı en fakir bölgedekinin iki katından daha fazla değildi. Bugün ise dünyadaki gelir adaletsizliği insanı dehşete düşürecek durumdadır. Bauman, (2014) Azınlı̆̆ın Zenginliği Hepimizin Çıkarına mıdır? başlıklı kitabında, dünyadaki gelir adaletsizliğinin ne boyutlarda olduğu göstermek adına, Avrupa ve ABD'deki çok az sayıdaki zengin ailenin servetinin neredeyse dünyanın geri kalanına eşit olduğunun ve önümüzdeki süreçte de bu durumun zenginlerin lehine işlemeye devam edeceğinin altını çizer.

Modernliğin "anlam" ve "ahlak" erozyonuna neden olduğu üzerinden kavramsallaştırılan "büyünün bozulması", günümüz toplumlarının içinde bulunduğu tüketim merkezli yaşam biçimlerinin de önemli etkenlerinden biridir. Ritzer'e (2011, s. 18) göre, günümüz insanının gündemini belirleyen en önemli şey, neyi, nasıl, nerede tüketeceğine ilişkin kaygılarıdır. Tüketime konu olan mal ve hizmetlerde sürekli bir artış ve çeşitlilik ile birlikte, bu kadar çok mal ve hizmetin tüketilmesini sağlayan, özendiren ve hatta zorlayan ortamların, yani "tüketim araçları"nın baş döndürücü bolluğu da dikkat çekmektedir. Ritzer (2011, ss. 14-26), "büyünün bozulduğu” modern 
dünyadaki "tüketim araçları"nı, bizi âdeta tüketime icbar eden yarı dinsel, büyülü niteliklere sahip "tüketim katedralleri" olarak tanımlar. Dolayısıyla Walt Disney Dünyası'ndan eğlence parklarına, alışveriş merkezlerinden, tatil amaçlı yapılan gemi seyahatlerine, zincir mağazalardan McDonald's gibi fastfood restoranlara kadar aklımıza gelebilecek her tür tüketim araçlarının sadece tüketime ortam/imkan sağlamadığı, aynı zamanda bizi tüketime yönelttiği ve hatta zorladığı görülmektedir. Ancak para kazanma hırsı ve tüketim çılgınlığı modern insana mutluluk getirmediği gibi, sağliktan çevreye kadar birçok problemi de beraberinde getirmiştir. Charlie Chaplin'in "Modern Zamanlar" filminde, üretim bandındaki işçinin öğle paydosunda yemekle zaman kaybetmemesi için yemek yediren bir makine icat edilmesi gibi, insanların üretim ve tüketim yapamadıkları uyku zamanlarına dahi göz dikilmiş durumdadır. Güzün Alaska'dan kuzey Meksika' ya, oradan da her bahar tekrar kuzeye doğru göç eden beyaz-taçlı serçe kuşlarının bir hafta boyunca uyumaksızın uçmalarından esinlenerek, insanların uyku "problemini”" ortadan kaldırarak, onları 7/24 savaşabilecek, çalışabilecek, tüketebilecek duruma getirmek için "bilimsel” çalışmalar yapılmaktadir (Crary, 2015).

Durning'in, (1998) Ne Kadar Yeterli? Tüketim Toplumu ve Dünyanın Geleceği başlığını taşıyan kitabı, günümüzün yoğun üretim ve çılgın tüketim sarmalını ele almakta ve bu gidişin ekolojik bir felakete neden olacağına dair bir çok örnek vermektedir. Bununla birlikte, bu çılgın tüketim alışkanlığı insanları mutlu edemediği gibi, komşuluk, arkadaşlık ve aile içi ilişkileri de yok etmiş, sosyal dayanışmayı ortadan kaldırarak insanları topluma ve doğaya karşı yabancılaştırmıştır. Ekonomist Robert Skidelsky ve felsefeci oğlu Edward Skidelsky de (2014) aynı şekilde, Ne Kadarı Yeterli? Para Sevgisi ve Iyi Yaşam Mücadelesi ismini verdikleri eserlerinde, iyi bir yaşamın ne olduğu, böyle bir yaşama ulaşmak ve onu sürdürmek için neler yapılması gerektiği gibi hayati sorulara cevap arayarak, hayattaki en önemli amacı daha fazla para kazanmak olan günümüz insanının geleceğine yönelik karamsar bir tablo ortaya koymaktadırlar.

Alain Touraine ise, (2014, ss. 123, 124) insanların eskiden sessizlik içinde yaşarken, şimdi gürültü içinde yaşadığını; eskiden yalnızlık çekerken, şimdi kalabalığın içinde kaybolduğunu; eskiden pek az mesaj alırken, şimdi mesaj bombardımanına tutulduğunu ifade eder ve dolayısıyla modern insanın eskisinden daha kötü bir durumda olduğuna dikkat çeker. Modernlik insanları, içinde yaşadıkları yerel kültürün dar sınırlarından çekip almış, bir yandan bireysel özgürlük dünyasının, öte yandan da kitle toplumu ve kültürünün içine atmıştır. Uzun zamandır eski düzenlere ve bu düzenlerin 
mirasına karşı savaşmış olan insanlar 20. yüzyılda "yeni” rejimlere karşı mücadele vermektedirler. Cemaatlerinden çıkmak ve hareket halindeki bir toplumun oluşumuna katılmak için can atan insanların, artık kalabalıktan, kirlilikten ve propagandadan kaçabilecekleri modern-öncesi bir yer kalmamıştır.

Modernliğe ait önemli tespitleri olan Han'ın, (2015) modernliğin sıkıntılarına yönelik tespitleri ise çok daha farklı konulara dikkat çekmektedir. Han, geçmişte bakteriyel ve viral hastalıklarla uğraşmış ve bir şekilde bunların üstesinden gelmiş olan insanlığın, 21. yüzyılda depresyon, dikkat eksikliği, hiperaktivite, sınırdaki kişilik bozukluğu veya tükenmişlik sendromu gibi sinirsel (neural) hastalıklarla uğraşmak zorunda kaldığını ve bu durumun gittikçe daha da ağırlaşacağını ifade eder. Han'a göre günümüz toplumu artık Foucault'nun tanımladığı gibi bir "disiplin” toplumu değil, “performans” toplumudur. Bu bakımdan Han'ın (2015) küçük ama önemli kitabının başlı̆̆ Yorgunluk Toplumu'dur.

Ülkemizdeki entelektüel/akademik çevrelerin Batı dünyasında modernliğe yönelik ortaya koyulan bu eleştirileri büyük oranda bildiği, ancak bu eleştirilerin "Batı toplumsal gerçekliği içinde üretilmiş olması" ve ayrıca Müslüman toplumlarda karşılığının ne olduğu konusunun yeterince dikkate alınmadığı söylenebilir.

\section{İrfani-Tasavvufi Anlayış ve Geleneğe Yönelik Tanım ve Yaklaşımlar}

İslam entelektüel geleneği içerisinde yer alan fikıh, hadis, tefsir, kelam, tasavvuf gibi disiplinlere yönelik çok kadim tartışmaların yanında, bu disiplinlerin yaşadığımız dünya içindeki konumları, bilgi üretme biçimleri, "modern" dünyanın problemlerine dair ne söylediği gibi konular devasa bir tartışma alanına işaret etmektedir. Bu makalenin konusu olan ve Müslüman toplumların dini hayatlarının şekillenmesinde başat bir rol oynamış irfani-tasavvufi anlayış ve geleneğin ise her zaman daha fazla bir ilgi ve tartışmaya konu olduğu söylenebilir.

İrfani-tasavvufi anlayış ve geleneğe ait yüzlerce tanımdan bahsedilmekle birlikte, tanımların içerisinde özellikle züht, takva, mahviyet, riyazet, mücahede gibi kavramların ön plana çıktığını ve bu kavramlarla dünyaya aşırı bağlanmamak, kalbi temiz tutmak, alçakgönüllü olmak, nefis ve şeytanla mücadele etmek gibi tutum ve davranışların kastedildiği anlaşılmaktadır (Yılmaz, 1994). Kelam ve felsefedeki teorik araştırmadan ziyade derunî müşahedeye ağırlık veren bu anlayış ve gelenek; insanın kendi hali, akıbeti ve Kur'an ayetlerinin anlamı üzerine düşünme (tedebbür), dış dünyanın etkilerinden mümkün olduğunca sıyrılarak ilahi ve ezeli hakikatler üzerine 
yoğun biçimde düşünme (teemmül); eşyanın mahiyeti, hakikat ve yaratılış hikmeti ve genel anlamda Allah'ın nimetleri üzerine düşünme (tefekkür); dünyanın ve içindekilerin geçici ve aldatıcı olduğuna dair düşünme (i’tibâr) biçimleri şeklinde tanımlanmaktadır (Kutluer, 2001, s. 63). Dolayısıyla bu anlayış ve gelenek içinde, kişinin dünyaya "elinikolunu kaptırmaması", dünya malına karşı tamahkârlık ve açgözlülük yapmaması, kalbini temiz tutmas1, nefsini terbiye etmesi, zarafet ve nezaket gibi tutum ve davranışlara sahip olması ve genel anlamda her yönüyle güzel ahlaklı olması vurgulanmaktadır (Eraydın, 1994, ss. 36-44; Öngören, 2011).

İrfani-tasavvufi anlayış ve gelenek tarihsel olarak birkaç dönem içerisinde değerlendirilmektedir. Birinci dönem, miladi 7. ve 8 . yüzyılları kapsayan züht dönemidir. İkinci dönem ise, sufi ve tasavvuf kavramlarının kullanılmaya başlandığı, tasavvufun müesseseleştiği, miladi 9. yüzyıldan tarikatların ortaya çıkmaya başladığı 13. yüzyıla kadar olan dönemdir. Üçüncü dönem ise, tasavvuf müesseselerinin en güçlüsü olan tarikatların ortaya çıkarak sosyal hayatın bir parçası haline geldiği 13 . yüzyıldan günümüze kadar devam eden zamanı ifade etmektedir (Knysh, 2011; Öngören, 2011; Y1lmaz, 1994, s. 84).

Züht dönemi içinde yer alan ilk sufilerin mistik olmaktan ziyade züht ve takva ehli oldukları ifade edilmektedir (Nickolson, 2004, s. 8). Bu dönemin en belirgin niteliği, marifetten çok amele, ilhamdan fazla ibadete, keşiften çok ahlaka, kerametten çok istikamete, kısacası nazariyeden çok amele önem verilmesidir (Uludağ, 1994, ss. 123, 124; Altıntaş, 1968). Züht hareketinin en meşhurlarından birisi olarak kabul edilen Hasan el-Basrî’in dini ve dini hayatı anlamada ortaya koyduğu paradigmanın temel esaslarında, yaratıcının razı olmadığı davranışlardan kaçınmaya yönelik insanın içinde duyduğu ürperti, çekinme ve sakınmanın ibadetlerden daha öncelikli bir yere sahip olduğu; kalbin çabuk kirlenmesinden dolayı kalbin temiz tutulmasına özen gösterildiği; nefsin dünyaya karşı iştiyakının dizginlenmemesi durumunda insanı kötü bir sona götüreceğinin farkında olunması gibi konuların yer aldığı görülmektedir (Nickolson, 2004, s. 39).

İrfani-tasavvufi anlayış ve gelenek içinde yer verilen birçok tutum ve davranışın, sadece bu anlayış ve geleneğe ait olmadığı, başta ahlak ilmi olmak üzere diğer İslami ilimler içinde de yer aldığı bilinmektedir. Ancak söz konusu tutum ve davranışların bu anlayış ve gelenek içinde hem daha fazla ön plana çıktığını hem de bu tür tutum ve davranışların kazanılması, içselleştirilmesi ve yaygınlaşmasına yönelik ciddi uygulamaların var olduğunu belirtmek gerekir. 
Kavramsal olarak irfani-tasavvufi anlayış ve gelenekle ilgili genel bir değerlendirme yapmak gerekirse; bu anlayış ve geleneğin ontolojik zeminin İslam'ın ilk dönemlerini kapsayan, sahabe, tabiun ve etbauttabiin zamanında oluştuğu ve makalenin tartışmaya açmak istediği anlayışın da, diğer dönemlere ait birikimleri de göz ardı etmeden, büyük oranda bu dönemi esas aldığı söylenebilir. Bu dönemdeki anlayışın oluşmasında, İslam peygamberinden sonra yaşanan sosyokültürel ve siyasi olayların büyük oranda etkili olduğu ifade edilebilir (Öngören, 2011). Tasavvuf kavramının ortaya çıktığı ve 13. yüzyıla kadar devam eden süreçte büyük oranda mayalanma dönemindeki anlayış korunmakla birlikte bir geleneğin de oluşmaya başladığı; doktriner tartışmalarla birlikte çeşitli ekollerin de ortaya çıtı̆̆ 1 görülmektedir. İrfani-tasavvufi anlayış ve gelenek içerisinde en tartışmalı dönemin, 13. yüzyıldan sonra tarikatların ortaya çıkmasıyla başlayan dönem olduğu anlaşılmaktadır. Batı Avrupa toplumlarında, Aydınlanma ile doruğa çıkan seküler ve rasyonalist eğilimlerin gölgelediği ve marjinalleştirdiği Hıristiyan mistisizminin aksine, irfani-tasavvufi anlayış ve geleneğin günümüz Müslüman toplumlarının sosyokültürel ve dini hayatını etkilemeye devam ettiği görülmektedir (Knysh 2011).

İrfani-tasavvufi anlayış ve geleneğin kendi içinde bir tutarlılığının olduğu söylenebilir. Ancak hiçbir disiplin sadece kendi içinde ve kendini ikna eden bir anlayışla; "anlayan anlar, anlamayanı ikna etmek zorunda değiliz" şeklinde bir ifadeyle kendine yönelik eleştirileri savuşturamaz (Kutluer, 2011, s. 131). Dolayısıyla her disiplin gibi, irfani-tasavvufi anlayış ve geleneğin de kendine yönelik, ilim, insaf, ahlak ölçülerinde yapılmış her türlü eleştiriye katlanmak ve cevap vermek durumunda olduğunu belirtmek gerekir. Bu anlayış ve geleneğin en temel probleminin, özeleştiri yapamayarak, bünyesinde hesabı verilmemiş birçok argümanın yerleşmesine firsat verdiği söylenebilir. Özellikle ezoterik/batıni unsurların yerleşmeye başladığı 10 . yüzyıldan sonra, mehdi anlayışından rüya, keşif, keramet, rabıta konularına kadar birçok konuda ciddi eleştirilere maruz kaldığı görülmektedir.

Her ne kadar irfani-tasavvufi anlayış ve gelenek kendini sorgulama ve eleştirileri dikkate almama eğiliminde olsa da, modernlikle birlikte hem doğrudan dini hedef alan "pozitivist", "seküler" çevreler hem de "İslamcı" çevreler tarafından ciddi olarak yıpratıldığı söylenebilir. Bununla birlikte, anlayış ve geleneğin en fazla kendilerini bu geleneğe nispet eden ancak "ahlak" ve "akıl" dişı birçok tutum ve davranışa sahip gruplarca itibarsızlaştırıldığını belirtmek gerekir. 
Din karşıtı ekollere mensup gruplar, bu anlayış ve geleneğe sahip insanları, hayatta veya ölmüş olan velileri ve türbeleri kutsal kabul etmekle, hurafelere inanmakla, modern dünyaya ayak uyduramamak ve karşı çıkmakla, ibadette aşırılığa kaçmakla ve eğitimsiz grupları kendi çıkarları için kullanmakla suçlamışlardır. İslamcılık düşüncesi içerisinde yer alan gruplar ise, bu anlayış ve geleneğin büyük oranda "bidat", "hurafe" ve hatta "şirk” varan anlayış ve uygulamalarından İslam'ın büyük zarar gördüğünü dile getirmişlerdir (Kara, 2003; Knysh 2011).

\section{İrfani-Tasavvufi Anlayış ve Geleneğin Modernliğin Sıkıntılarına Çözüm Oluşturma İmkânı}

Makalenin başında en bilindik örnekleri üzerinden özetlemeye çalıştı̆̆ımız modernliğe dair sıkıntıların başında "anlam" ve "ahlak" krizi yer almaktadır. MacIntyre'ın (2001) tespitiyle, bir afet gibi insanlığın üzerinden geçen modernlik, büyük oranda ahlaki bütünlügü parçalayarak yok etmiş; ahlak adına geride sadece bir takım fragmanlar bırakmıştır. Taylor'un, (2011, ss. 10, 11) "ahlaki ufukları soldurdu" dediği modernliğin, Batı toplumları için söz konusu edilen sıkıntılarının daha fazlasının Batı dışı ve Müslüman toplumlar için geçerli olduğu tartışılabilir. Çünkü "büyüsü bozularak" (Ritzer, 2011; Weber, 1993, s. 136) “Büyük Varoluş Zinciri”nin (Taylor, 2011, ss. 10-13) bir parçası olmaktan çıkan Batı toplumlarının, insanların çoğunluğunun sahip olduğu düşünülen sayg1, nezaket, hoşgörü, dürüstlük gibi özelliklerin, "içselleştirilmiş" ve "derinliği" olan tutum ve davranışlar olup olmadığı tartışması bir yana; eğitim sistemi, toplumsal ve hukuki müeyyidelerle birlikte büyük oranda bu tür tutum ve davranışları içeren "seküler bir ahlak" oluşturabildikleri söylenebilir. Ancak, modernliğin, geleneksel formları büyük oranda tahrip ettiği Batı dışı ve Müslüman toplumlarda yeni bir form inşa edilemediği görülmektedir.

Bugün Batı toplumlarının hararetle savunduğu demokrasi, eşitlik, özgürlük, insan hakları ve şiddetle karşı çıktığı terör, 1rkçılık gibi konularda Batı dışı toplumlara ve özellikle Müslümanlara karşı “tescilli bir ikiyüzlülük” içinde oldukları söylenebilir. Diğer taraftan, Batı dünyasıyla mukayese edildiğinde, trafik kurallarına uymaktan, hakka-hukuka riayet etmeye; iş-ticaret ahlakından, toplumsal nezakete, dürüstlükten nezaket kurallarına uymaya ve entelektüel/akademik üretime kadar, kişisel ve toplumsal hayata dair hemen her konuda Müslüman toplumları mahcup eden bir durumun olduğu genel kabul gören bir tespittir.

Batı dünyasında, çocuğu, torunu, akrabası olmamasına rağmen, kendinden sonraki insanların yaşamları için gerekli olan havanın, suyun, toprağın kirletilmemesine 
son derece dikkat eden birçok insan varken, Müslümanların yaşadığı coğrafyalarda büyük oranda toprağın, suyun ve havanın ağır tahribat altında olduğu görülmektedir. Sadece ülkemizde her yıl tonlarca kullanılan ısırgan ilacı ve diğer tarım ilaçlarının, en başta toprak ve suyun zehirlenmesiyle ülkenin geleceğine olan ağır maliyeti "küçük" bir örnek olarak verilebilir.

Her ne kadar ölçme kriterleri tartışılabilir olsa da, George Washington Üniversitesi'nden Scheherazade S. Rehman ve Hossein Askari (2010) tarafından yapılan, "Ekonomik İslamilik indeksi” ve "İslam ülkeleri ne kadar İslami?" başlıklı makalelerde, "İslamilik İndeksi" olarak belirlenen kriterlere göre, 57 tane İslam ülkesinin yer aldığı toplam 208 ülkeyi kapsayan araştırmanın sonucunda ortaya çıkan listenin ilk 37'sinde hiçbir İslam ülkesinin yer almaması dikkat çekici örneklerden biridir. Dolayısıyla İslam ülkeleri dışındaki ülkelerin ve özellikle Avrupa ve ABD’nin yer aldığı Batı ülkelerinin eğitim, toplumsal nezaket, trafik, çalışma şartları, güvenlik, adalet, şehirleşme, mimari, ulaşım, yeşil ve tarım alanlarının korunması gibi daha birçok konuda çok daha "iyi” durumda oldukları görülmektedir. Ancak bütün bunlar Batılı toplumların çok "sağlam", "sarsılmaz" bir yapıya sahip olduğu anlamına gelmemektedir. Batıda tecavüz, cinayet, bireysel silahlanma gibi toplumsal sorunların yaygın olarak görüldüğü bilinmektedir. Bu toplumların olumlu özeliklerinin yanı sıra, aynı zamanda kolay bir şekilde manipüle edilerek ciddi toplumsal kargaşalarla karşılaşabildiği; bir fırtına haberiyle bile insanların marketleri boşaltabildiği ve hatta doğal bir afet durumunda insanların dükkânları yağmalayabildiği; dolayısıyla "iyi" olarak görülen birçok tutum ve davranışın "sahiciliğinin” de tartışılabilir olduğunu belirtmek gerekir. Bu bağlamda, Batı toplumlarının sahip olduğu "seküler ahlakın" ne kadar sürdürülebilir olduğu; bu tip bir "ahlakın" zaman içerisinde Batı dışı toplumlarda da oluşup-oluşamayacağı gibi meselelerin oldukça tartışmalı olduğunu söyleyebiliriz.

Burada dikkat çekilmek istenen konu, Batı dışı ve Müslüman toplumların "geleneksel" referans alanlarının modernlik tarafından büyük oranda tahrip edildiği ve iş göremez hale geldiği; diğer taraftan modernliğin yeni bir referans alanı da oluşturamadığıdır. Bu noktada hem Batı toplumlarında hem de Batı dışı ve Müslüman toplumlarda irfani-tasavvufi anlayış ve geleneğin "anlam" ve "ahlak" inşa etme sürecinde önemli bir referans alanı olabileceği söylenebilir.

$\mathrm{Bu}$ makalenin, Müslüman toplumların on yıllardır süren "modernleşme" hikâyeleri içinde yer alan; “Aslında İslam dini her yönden iyidir”, “Ancak 'doğru’ bir İslam anlayışıyla kurtulabiliriz” veya "İslam birçok anlayış ve uygulamasıyla modern 
dünyada yaşanılabilir bir din değildir" şeklinde özetlenebilecek tartışmalara geri dönmek gibi bir derdi olmadığı belirtilmelidir. Yukarıda verilen örnekler Batı toplumlarının birçok açıdan daha "iyi” bir durumda olduğunu vurgulamak maksadiyla verilmemiştir. Dolayısıyla tartışmanın "Müslüman veya Batı toplumlarının iyi veya kötü/daha iyi veya daha kötü” olduğu ikiliğinden çıkarılması gerektiği söylenmeye çalışılmaktadır.

Yukarıda bahsedildiği gibi Taylor'un (2011, s. 10) modernlik eleştirisinin en önemli başlıklarından birini "bireycilik" oluşturmaktadır. Batı toplumsal pratikleri üzerinden yapılan tespit, eleştiri ve yorumlara dayalı olarak ortaya konulan bireycilik meselesinin, hem Batı toplumlarında hem de Batı dışı ve Müslüman toplumlardaki durumunu belirli sorular ile gözden geçirmek mümkündür: Batı toplumları bahsedildiği kadar "bireyci" toplumlar midır? Batı toplumlarının "bireyci" olduklarına dair verilen örneklere karşılık, "bireyci" olmadığına dair de birçok örnek verilemez mi? Batı toplumları için bir "problem" olarak dile getirilen "bireycilik”, Müslüman toplumlar söz konusu olduğunda, tam tersine, problem "bireyin" yok edilmesi/sayılması olarak değerlendirilemez mi? Özel hayatın korunması ve saygı duyulması gibi konularda Batılı ve Müslüman toplumlar karşılaştırıldığında nasıl bir tablo ortaya çıkmaktadır? Bu bağlamda, irfani-tasavvufi gelenek, bireyciliğin Batı toplumlarında ortaya çıktığı şekline çözüm sunabilecek bir pozisyondayken, "bireycilik" probleminin karşıt bir noktadan; "bireyselleşememe" vurgusundan tartışılabilir olduğu Müslüman toplumlarda sıkıntıyı çözebilecek bir noktada durmamaktadır.

Modernliğin bir diğer sıkıntısı olarak dile getirilen "araçsal aklın öncelik kazanması" meselesi de, Batı ve Müslüman toplumların pratikleri üzerinden tartışılmaya değer bir konu olarak durmaktadır. Batıda, hemen her alanda belirleyici olduğu söylenen "verimlilik", "maliyet", "fayda" ve "çıkar" gibi kavramların geçerliliği yanında, kendi içinde tutarlılığı olan, "kitaba uygun" bir rasyonelliğin de olduğu görülmektedir. İnsanların çoğunlukla neyi nasıl yapacaklarını, süreçleri ve sonuçları öngörebilmeleri söz konusu iken; Müslüman toplumlarda ise gündelik işlerin "kitabına uydurulabildiği" bir belirsizlik ve öngörülemezlik söz konusudur. Bu minvalde, Müslüman toplumlar için "verimlilik", "maliyet", "fayda" gibi kavramların ön planda olduğu bir toplumsal yapıdan bahsetmek zor olduğu gibi; “ahlaklı", erdemli”, "rasyonel" bir yapıdan da bahsetme imkânı da oldukça sınırlıdır. Dolayısıyla, İrfanitasavvufi anlayış ve geleneğin, modernliğin önemli sıkıntılarından biri olarak ortaya koyulan, "aklın araçsallaştırılması" konusunda Batı toplumları için çözüm oluşturabilme imkânına sahip iken, araçsal aklın gündelik yaşam pratiklerini 
yönlendirmediği Müslüman toplumlar için böyle bir imkândan yoksun olduğu söylenebilir.

Yukarıda bahsedildiği gibi, modernlik insanları gündelik hayattaki sözde konfora razı ederek, görünüşte “demokratik”, “özgürlükçü”, “eşitlikçi” ama gerçekte hiç de öyle olmayan bir siyaset alanına hapsetmektedir (Taylor, 2011, ss. 15, 16). Avrupa'da ve özellikle ABD'de de yapılan seçimlerin büyük oranda başta televizyonlar ve gazeteler olmak üzere kitle iletişim araçlarının yoğun etkisi altında yapıldığı ve hatta kitle iletişim araçlarının bireylerin yaşamını şekillendirme hususunda yasama, yürütme ve yargıdan daha fazla güce sahip olduğu ifade edilmektedir (Oswald, 1994). Toplumun sosyo-politik ilgisinin çok düşük olduğu ve özel yaşamında keyfini kaçıracak bir şey olmadığı sürece güncel meselelerle ilgilenmediği; çoğunlukla televizyon ve gazetelerin verdiği haberlerin doğruluğunu sorgulama ihtiyacı hissetmeden kabullendiği anlaşılmaktadır. Çoğu Müslüman toplumda ise sosyo-politik alan ya toplumun büyük çoğunluğunu dışarıda tutarak ya da çok azını işin içine katarak şekillenmektedir. Türkiye'de ise sosyo-politik alana ilgi ve katılımın yüksek olması yanında, bunun “nitelikli” ve “dönüştürücü” bir etkiye sahip olduğunu söylemek güçtür. İrfani-tasavvufi anlayış ve geleneğin bu alandaki "düzeltici" ve "dönüştürücü” imkânının da, "bireycilik" ve "aklın araçsallaştırılması" meselelerinde olduğu gibi oldukça tartışmalı olduğunu belirtmek gerekir.

Modernliğe dair eleştirilerin en dikkat çekici olanlarından bir diğeri ise "gelir adaletsizliği”, "üretim ve tüketim çılgınlı̆̆ı” gibi sosyo-ekonomik alana dair konulardır. Çünkü modern toplumlar, önlerinde duran ihtiyaç listelerinin gerçekliğini sorgulayamaz durumda olan insanların oluşturduğu, "varlığgl" ve "mutluluğu” tüketime bağlı, "tüketim toplumlarıdır" (Baudrillard, 2008). Batı toplumları ve Müslüman toplumlar üretim ve tüketim konuları karşılaştırıldığında farklılık göstermektedir. Batı toplumlarında üretim ve tüketim "çılgınlığı"ndan bahsedilirken, Müslüman toplumlarda çoğunlukla tüketim "çılgınlığı"ndan bahsedilebilir. Modern insanın içinde bulunduğu para kazanma hırsı ve tüketim çılgınlığı için Durning (1998) ve Skidelsky’lerin (2014) gündeme getirdikleri "Ne kadarı yeterli?" sorusu, irfani-tasavvufi anlayış ve gelenek içinden bakıldığında anlamlı bir soru olarak durmaktadır. Çünkü bu geleneğin en güçlü tarafının, insanların dünya malına yönelik düşkünlüğünü azaltmak ve servet yığmalarını engellemek olduğu ifade edilmektedir. Bununla ilintili olarak ele alınabilecek olan bir başka husus da "israf" meselesidir. Bauman, (2013, s. 38) bu konuyu, "Bana firlatıp attığın şeyi söyle, sana kim olduğunu söyleyeyim!” cümlesiyle çarpıcı bir şekilde ortaya koymuştur. Bir örnek olması bakımından, Toprak Mahsulleri Ofisi'nin (TMO, 2013) 2013 yılında ülke 
genelinde yaptığı araştırmada, günlük üretilen 90 milyon civarındaki ekmeğin yaklaşık 5 milyonunun çöpe atıldığı tespit edilmiştir. Bu rakam açıkça yaklaşık 5 milyon insanın günlük ekmek ihtiyacına denk gelmektedir. Ekmeğin kutsal "nimet" olarak kabul edildiği ülkemizde, yılda 2 milyar civarında ekmeğin çöpe atıldığı anlaşılmaktadır. Dolayısıyla tüketim çılgınlığı ve israf konularında, en önemli prensipleri arasında hiç bir nimetin israf edilmemesi ve dünya malına tamah edilmemesi olan irfani-tasavvufi anlayış ve geleneğin modern dünyaya çözüm oluşturma imkânı sunduğu söylenebilir.

Modernliğe yönelik dikkat çekici tespit ve eleştirileri olan Han (2015) ise, günümüz toplumlarının karşı karşıya olduğu en ciddi problemlerin sinirsel (neural) hastalıklar olduğunu ifade eder. Modernliğin yukarıda sayılan problemleri Batı ve Müslüman toplumlar için bazı farklılıklar gösterse de, bu problemin bütün toplumları ciddi oranda etkileyebileceği anlaşılmaktadır. Dünya Sağlık Örgütü'ne göre depresyonun 2020 yılında, yaşam kalitesini bozan ve yeti yitimine yol açan hastalıklar arasında birinci sırayı alacağı tahmin edilmektedir (Sezgen, 2016). İrfani-tasavvufi anlayış ve geleneğin, insanların iç dünyasını düzenleyip "iyileştirerek" onları içlerinden yakalamayı başaran eğitsel gücünün son derece yüksek olması nedeniyle (Kutluer, 2011, s. 131), modernliğin ortaya çıkardığı sinirsel (neural) hastalıklara ve çıkmazlara çözüm olabilme imkânının da oldukça yüksek olduğu söylenebilir.

\section{Sonuç}

Makale, modernliğin sıkıntıları bağlamında dile getirilen "bireycilik", "araçsal aklın öncelik kazanması", "siyasal alana ilgisizlik", "üretim ve tüketim çılgınlığı", "sinirsel (neural) hastalıklar" gibi konularda irfani-tasavvufi anlayış ve geleneğin, Batı ve Müslüman toplumlar için çözüm oluşturma imkânını tartışmaya açmayı amaçlamıştır. $\mathrm{Bu}$ yüzden, makalede yer alan tespitler, amaçlanan bu tartışmaya başlangıç düzeyinde bir katkı olarak değerlendirilmelidir.

Modernliğin sıkıntıları içinde yer alan "bireycilik" ve "aklın araçsallaştırılması" meselelerinin, Batı ve Müslüman toplumlar için farklı şekillerde değerlendirilmesi faydalı olacaktır. İrfani-tasavvufi anlayış ve geleneğin, Batı toplumlarının bu sıkıntılarına dair çözüm oluşturma imkânı söz konusu iken, Müslüman toplumlar için aynı imkânı sunmadığı; tüketim, israf ve sinirsel hastalıklar gibi konularda ise hem Batı hem de Müslüman toplumlar için çözüm oluşturma imkânının oldukça fazla olduğu söylenebilir. Ancak bu imkânın, bu anlayış ve geleneğin kendisine yönelik yapılan eleştirileri ciddiye alarak, öz eleştiri yapabilmesiyle yakından ilgili olduğunu da belirtmek gerekir. 
Bugüne kadar irfani-tasavvufi anlayış ve geleneğe karşı "toptancı" yaklaşımların hiçbir fayda vermediği görülmüştür. Toplumsal yapıyı etkileme gücü yüksek olan bu geleneğin, yüzyıllardır yetiştirdiği ve İslam entelektüel geleneğine kazandırdığı önemli isimlerin ve onların eserlerinin üzerine nitelikli çalışmalar yapılmasının bu anlayış ve geleneğin teorik yapısını güçlendireceği söylenebilir.

İrfani-tasavvufi anlayış ve geleneğin, modern dünyanın bunalımlarına "yegâne" çözüm olarak değil, sunabileceği katkı bağlamında değerlendirilmesi gerekmektedir. Bu bağlamda, bu anlayış ve geleneğin sosyoloji, psikoloji, pedagoji, eğitim gibi alanlarla irtibatını kurabilecek sosyal bilim çalışmalarına ihtiyaç olduğu söylenebilir.

\section{Kaynakça}

ALTINTAŞ, H. (1986). Tasavvuf Tarihi, Ankara: Ankara Üniversitesi Basımevi.

BAKIRCI, M. (2016). Modern Dünyanın Bunalımlarına Tasavvufî/İrfani Yaklaşımların/Geleneğin Çözüm Oluşturma İmkânı-Hoca Ahmed Yesevi Örneği. Geçmişten Geleceğe Hoca Ahmet Yesevi Uluslararası Sempozyumu, ed. Ö. Kul ve diğerleri, Cilt: 2, ss. 927-944, İstanbul.

BAUDRİLlARD, J. (2008). Tüketim Toplumu, çev. H. Deliçaylı, F. Keskin, İstanbul: Ayrıntı Yayınları.

BAUMAN, Z. (2013). Azınlı̆̆ın Zenginliği Hepimizin Çıkarına mıdır? çev. H. Keser, İstanbul: Ayrıntı Yayınları.

CRARY, J. (2015). 7/24: Geç Kapitalizm ve Uykuların Sonu, çev. N. Çatl1, İstanbul: Metis Yayınları.

DURNING, A. T. (1998). Ne Kadarı Yeterli? Tüketim Toplumu ve Dünyanın Geleceği, çev. S. Çağlayan, Ankara: Tübitak-Tema Vakfi Yayınları.

EİSENSTADT, S. N. (2007). Modernleşme Başkaldırı ve Değişim, Ankara: Doğu Batı Yayınları.

EİSENSTADT, S. N., Sachsenmaier, D., \& Riedel, J. (2002). Reflections on Multiple Modernities: European, Chinese and Other Interpretations, Leiden: Brill. 
ERAYDIN, S. (1994). Tasavvuf ve Tarikatlar, İstanbul: Marmara Üniversitesi İlâhiyat Fakültesi Vakfı Yayınları.

GIDDENS, A. (1996). The Consequences of Modernity, Cambridge: Polity Press, John Wiley \& Sons.

GÖLE, N. (2004). Batı Dışı Modernlik: Kavram Üzerine. Modern Türkiye'de Siyasî Düşünce: Modernleşme ve Batıcılık, ed. U. Kocabaşoğlu, Cilt: 3, ss. 56-67. İstanbul: İletişim Yayınları.

HAN, B. C. (2015). Yorgunluk Toplumu, çev. S. Yalçın, İstanbul: Açılım Kitap.

HORKHEİMER, M. (1998). Akıl Tutulması, çev. O. Koçak, İstanbul: Metis Yayınları.

KARA, İ. (2003). Din ile modernleşme Arasında: Çağdaş Türk Düşüncesinin Meseleleri, İstanbul: Dergâh Yayınları.

KNYSHK, A. (2011). Tasavvuf Tarihi, çev. İ. Durdu, İstanbul: Ufuk Kitapları.

KUTLUER, İ. (2001). İlim ve Hikmetin Aydınlığında, İstanbul: İz Yayınc1lık.

MACINTYRE, A. (2001). Erdem Peşinde, çev. M. Özcan, İstanbul: Ayrıntı Yayınları.

NİCKOLSON, R. A. (2004). İslâm Sûfỉleri, çev. Y. Belli, M. Temelli, Ankara: Çağlar Yayınları.

OSWALD, K. A. (1994). Mass Media and the Transformation of American Politics, Marquette Law Review, 77(2), 385.

ÖNGÖREN, R. (2011). Tasavvuf, DİA, Cilt: 40, ss. 121-124. İstanbul: TDV Yayınevi

POLANYİ, K. (2001). 1944. The Great Transformation: The Political and Economic Origins of Our Times, Boston: Beacon Press.

REHMAN, S. S., \& Askari, H. (2010). An Economic İslamicity index, Global Economy Journal, 10(3).

REHMAN, S. S., \& Askari, H. (2010). How İslamic are İslamic Countries? Global Economy Journal, 10(2).

RİTZER, G. (2011). Büyüsü Bozulmuş Dünyayı Büyülemek, çev. Ş. S. Kaya, İstanbul: Ayrıntı Yayınları. 
SEZGEN, A. (2016). Lise Öğrencilerinin Antidepresan Kullanma Durumlarl ve Bunu Etkileyen Faktörlerin Belirlenmesi (Yayınlanmamış yüksek lisans tezi), Koç Üniversitesi, İstanbul.

SKİDELSKY, E., \& Skidelsky, R. (2014). Ne Kadar Yeterli? Para Sevgisi ve Iyi Yaşam Mücadelesi, çev. L. Konyar, İstanbul: İstanbul Bilgi Üniversitesi Yayınları.

SOLMAZ, B. (2011). Modernlik ve Modernleşme Kuramlarına Yöneltilen Eleştiriler, Selçuk Üniversitesi İlahiyat Fakültesi Dergisi, 32(32), ss. 35-58.

TAYLOR, C. (2011). Modernliğin Sıkıntıları, çev. U. Canbilen, İstanbul: Ayrintı Yayınları.

TMO, (2013). Türkiye'de Ekmek İsrafı Araştırması, Ankara: Toprak Mahsulleri Ofisi.

TOURAİNE, A. (2014). Modernliğin Eleştirisi, çev. H. U. Tanrı̈ver, İstanbul: Yapı Kredi Yayınları.

ULUDAĞ, S. (1994). İslam Düşüncesinin Yapısı, İstanbul: Dergâh Yayınları.

ÜNAL, M. S. (2011). Dinsel Bireycilik, İstanbul: Açılım Kitap.

WEBER, M. (1993). Sosyoloji Yazıları, çev. T. Parla, İstanbul: Hürriyet Vakfı Yayınları.

YILMAZ, H. K. (1994). Anahatlartyla Tasavvuf ve Tarîkatlar: Tarihi, Kavramlarl ve Mes'eleleri, İstanbul: Ensar Neşriyat. 